\title{
PENGEMBANGAN MODEL BIMBINGAN KELOMPOK TEKNIK OUTBOUND UNTUK MENINGKATKAN KOMUNIKASI ANTAR PRIBADI MAHASISWA
}

\author{
Mulyani \\ Prodi Bimbingan dan Konseling, FKIP, Universitas Pancasakti Tegal mulyanibk@gmail.com \\ Renie Tri Herdiani \\ Prodi Bimbingan dan Konseling, FKIP, Universitas Pancasakti Tegal, renie3_psy.yahoo.co.id
}

\begin{abstract}
Abstrak
Dalam kehidupan sehari-hari, komunikasi antar pribadi akan selalu terjadi tak terkecuali di lingkungan kampus. Kemampuan komunikasi antar pribadi dikalangan mahasiswa sangatlah beragam.Seperti halnya yang terjadi di lingkungan kampus UPS Tegal, berdasarkan hasil observasi kami terhadap mahasiswa FKIP UPS Tegal khususnya prodi Bimbingan dan Konseling. Mahasiswa yang memiliki komunikasi antar pribadi yang baik mempunyai indikasi seperti mudah dalam bergaul, aktif berorganisasi, banyak teman, peka terhadap lingkungan, dll.Tujuan dari penelitian ini adalah untuk mengetahui:1) kondisi riil komunikasi antar pribadi mahasiswa sebelum pelaksanaan bimbingan kelompok teknik outbound ,2) Untuk komunikasi antar pribadi mahasiswa setelah pelaksanaan Bimbingan Kelompok Teknik Outbond?, 3) Untuk Mengetahui apakalah model Bimbingan Kelompok Teknik Outbond dapat meningkatkan Komunikasi Antar Pribadi Mahasiswa.Metode Penelitian ini adalah Sesuai dengan permasalahan dan tujuan penelitian, penelitian ini menggunakan jenis penelitian dan pengembangan atau Research and Development (R\&D), yaitu jenis penelitian yang digunakan untuk menghasilkan produk tertentu, dan menguji keefektifan produk tersebut (Borg \& Gall dalam Sugiyono 2010: 407-409).Hasil Penelitian adalah bahwa komunikasi antar pribadi mahasiswa sebelum pemberian layanan bimbingan kelompok dengan teknik outbond komunikasi antar pribadi mahasiswa sebelum diberikan layanan bimbingan kelompok dengan teknik outbond, menghasilkan interval 103-108, yaitu sebanyak 12 mahasiswa dengan persentase 40\% yang tergolong dalam kriteria rendah Komunikasi antar pribadi mahasiswa setelah pemberian layanan bimbingan kelompok dengan teknik outbond penelitian menghasilkan interval 121-126, yaitu sebanyak 15 mahasiswa dengan persentase 50\% yang tergolong dalam kriteria tinggi. Berdasarkan hasil analisis dengan perhitungan statistik menggunakan $\mathrm{t}-$ test di atas diperoleh thitung $=4,763$ dengan taraf signifikansi $1 \%$ dan drajat kebebasan $\mathrm{N}-1=30-1=29$, maka didapat ttabel $=2,756$. Maka dapat disimpulkan bahwa Model Bimbingan Kelompok Teknik Outbond dapat meningkatkan komunikasi antar pribadi mahasiswa prodi BK FKIP UPS Tegal.Kesimpulan bahwa layanan bimbingan kelompok, mempunyai peran penting dalam mengembangkan kemampuan berinteraksi atau berkomunikasi serta dapat meningkatkan komunikasi antar mahasiswa

Kata Kunci : Bimbingan Kelompok Teknik Outboud, Komunikasi Antar Pribadi
\end{abstract}

\begin{abstract}
In everyday life, interpersonal communication will always happen no exception in the campus environment. Interpersonal communication skills among students is beragam.Seperti case in Tegal UPS campus environment, based on our observations of the student FKIP UPS Tegal particularly Prodi Guidance and Counseling. Students who have good interpersonal communication have an indication as easy to get along, actively organize, many friends, sensitive to the environment, dll.Tujuan of this study was to determine: 1) the real condition of interpersonal communication between students before the implementation of outbound group counseling techniques, 2) for interpersonal communication students after the implementation of the Guidance Group Outbound Techniques ?, 3) to Know apakalah Outbound Engineering Group Guidance models can improve inter-personal communication
\end{abstract}


Mahasiswa.Metode this study is accordance with the problems and research objectives, this research using this type of research and development or research and Development $(\mathrm{R} \& \mathrm{D})$, which is a type of research that is used to produce a particular product, and test the effectiveness of these products (Borg \& Gall in Sugiyono 2010: 407-409) the results was that the study of interpersonal communication students before administration of group counseling services den gan outbound engineering student interpersonal communication before the given group counseling service with outbound techniques, producing interval 103-108, as many as 12 students with a percentage of $40 \%$ were classified in the low criteria interpersonal communication students after the administration of guidance services research group with outbound techniques produce interval 121-126, as many as 15 students with a percentage of $50 \%$ belonging to the high criteria. Based on the analysis with statistical calculations using $\mathrm{t}$-test is obtained $\mathrm{t}=4.763$ with $1 \%$ significance level and degrees of freedom $\mathrm{N}-1=30-1=29$, then gained the table $=2.756$. It can be concluded that the Model Guidance Outbound Engineering Group can improve interpersonal communication students Prodi BK FKIP UPS Tegal.Kesimpulan that guidance services group, has an important role in developing the ability to interact or communicate as well as to improve communication between students

Keywords: Guidance Outboud Engineering Group, Inter-Personal Communication

\section{PENDAHULUAN}

Hakikat manusia sebagai mahluk sosial tentu tidak lepas dari pergaulan antar sesama baik dilingkungan keluarga, kerja, sekolah maupun tempat-tempat keramaian lainnya. Manusia sebagai mahluk sosial tentu membutuhkan kehadiran seseorang dimanapun dan kapanpun juga mereka berada tanpa terkecuali. Manusia selalu bergantung hidupnya dengan manusia lainnya. Oleh karena itu dalam kehidupan manusia selalu terjadi interaksi, untuk memperlancar hubungan antar manusia tentu dibutuhkan komunikasi yang baik. Kesuksesan kehidupan sosial seseorang sangatlah dipengaruhi oleh proses komunikasi antar pribadi yang dijalaninya, tanpa adanya komunikasi maka tidak akan mungkin ada kehidupan yang harmonis.

Dalam kehidupan sehari-hari, komunikasi antar pribadi akan selalu terjadi tak terkecuali di lingkungan kampus. Kemampuan komunikasi antar pribadi dikalangan mahasiswa sangatlah beragam. Ada yang mempunyai komunikasi antar pribadi yang baik, sedang ada pula yang jelek. Seperti halnya yang terjadi di lingkungan kampus UPS Tegal, berdasarkan hasil observasi kami terhadap mahasiswa FKIP UPS Tegal khususnya prodi Bimbingan dan Konseling. Mahasiswa yang memiliki komunikasi antar pribadi yang baik mempunyai indikasi seperti mudah dalam bergaul, aktif berorganisasi, banyak teman, peka terhadap lingkungan, dll. Begitu juga sebaliknya mahasiswa yang mempunyai kemampuan komunikasi antar pribadi yang rendah akan terlihat dengan indikasi sulit untuk bergaul dengan orang lain (hanya mempunyai teman itu saja). Berdasarkan hasil observasi dapat disimpulkan bahwa tidak sedikit di lingkungan mahasiswa khususnya prodi Bimbingan dan Konseling memiliki kemampuan komunikasi antar pribadi yang kurang baik, mengingat komunikasi adalah faktor yang paling penting dalam kehidupan sehari-hari apalagi mahasiswa prodi BK yang merupakan calon konselor diharapkan mampu berkomunikasi yang baik sehingga secara khusus bisa menjalin hubungan yang baik dengan klien, atas pertimbangan tersebut kami tertarik ingin membantu meningkatkan komunikasi antar pribadi mahasiswa melalui layanan bimbingan kelompok teknik outbound.

Pemberian layanan bimbingan yang bersifat kelompok kepada mahasiswa dinilai sangat tepat karena dengan sistem berkelompok mahasiswa akan lebih nyaman terlebih lagi dengan menggunakan teknik outbound sehingga tujuan dari pemberian layanan akan mudah tercapai dengan baik yaitu meningkatkan komunikasi antar pribadi mahasiswanya. Bimbingan kelompok teknik outbound adalah suatu kegiatan bimbingan yang dilakukan secara kelompok dan dilakukan di alam terbuka dengan cara melakukan permainan-permainan khusus yang mempunyai tujuan yang berbeda-beda. Selain itu, menurut kami memberikan bantuan melalui layanan bimbingan kelompok dengan berbagai jenis teknik untuk meningkatkan suatu hal dinilai sangat efektif karena hal tersebut sudah banyak dibuktikan melalui penelitianpenelitian sebelumnya.

Salah satu hasil penelitian terdahulu yang berkaitan dengan penelitian kami adalah penelitian yang dilakukan oleh Imam Subagyo dengan judul "Bimbingan Kelompok Dengan Teknik Outbound Untuk Meningkatkan 
Penyesuaian Diri Siswa", hasil penelitian menyebutkan bahwa bimbingan kelompok dengan teknik outbound efektif untuk meningkatkan penyesuaian diri siswa (http://www.e-jurnal.com/2014/05/bimbingan-kelompokdengan-teknik.html). Melalui kegiatan bimbingan kelompok teknik outbound ini diharapkan mahasiswa dapat belajar tentang keterampilan sosial melalui pengalaman, selain itu karena dilakukan di luar ruang dengan permainan-permainan sehingga diharapkan akan lebih nyaman dan menikmati.

Berdasarkan penelitian sebelumnya dan permasalahan yang ada maka kami tertarik untuk mengembangkan model bimbingan kelompok teknik outbound agar lebih efektif dalam meningkatkan komunikasi antar pribadi. Oleh karena itu kami akan melakukan penelitian dengan judul "Pengembangan Model Bimbingan Kelompok Teknik Outbound Untuk Meningkatkan Komunikasi Antar Pribadi Mahasiswa"..

\section{METODE PENELITIAN}

Sesuai dengan permasalahan dan tujuan penelitian, penelitian ini menggunakan jenis penelitian dan pengembangan atau Research and Development (R\&D), yaitu jenis penelitian yang digunakan untuk menghasilkan produk tertentu, dan menguji keefektifan produk tersebut (Borg \& Gall dalam Sugiyono 2010: 407-409). Peneliti berupaya merumuskan pengembangan produk yaitu pengembangan model bimbingan kelompok dengan teknik outbound untuk meningkatkan komunikasi antar pribadi mahasiswa yang kemudian diuji, divalidasi dan diaplikasikan. Penelitian ini menggunakan pendekatan kuantitatif. Pendekatan kuantitatif digunakan untuk mengkaji tingkat komunikasi antar pribadi mahasiswa dan keefektifan model bimbingan kelompok teknik outbound untuk meningkatkan komunikasi antar pribadi mahasiswa. Pada tataran teknis dilakukan langkah dengan metode analisis deskriptif dan metode quasi eksperimen.Analisis bimbingan kelompok teknik outbound untuk meningkatkan komunikasi antar pribadi mahasiswa dilakukan dengan menganalisis tingkatan komunikasi antar pribadi mahasiswa sebelum dan sesudah mengikuti bimbingan kelompok .
(pre-test)
0_1
Treatment
$\mathrm{X}$
(post-test)
0_2

Gambar 3.1

One-Grup pretest-posttest Design (Sugiono, 2009:75)

Keterangan :

0_1 : Pre-test, Pengukuran untuk mengukur tingkat kemampuan komunikasi antar pribadi sebelum dilakukan Bimbingan Kelompok dengan teknik Outbont .
$\mathrm{X}$ : Treatment atau perlakuan yaitu pelaksanaan bimbingan kelompok dengan teknik outbont terhadap mahasiswa UPS Tegal.
02 : Post-test,

Pengukuran untuk mengukur tingkat kemampuan komunikasi antar pribadi sesudah dilakukan bimbingan kelompok dengan teknik

Perencanaan dan rancangan desain produk model bimbingan kelompok dengan teknik outbond untuk meningkatkan kumunikasi antar pribadi mahasiswa yang akan dikembangakan dan diuraikan dalam langkahlangkah konkrit yang nantinya akan diberikan kepada mahasiswa secara jelas dan rinci. Berikut gambarnya:

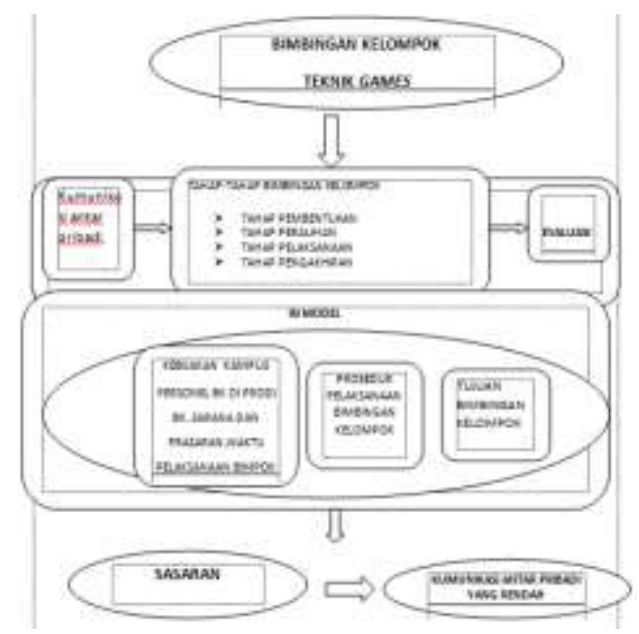

\section{Hasil Penelitian}

Pembahasan pada temuan penelitian ini dipaparkan sesuai dengan prosedur penelitian yang telah dilakukan.Temuan ini memberikan gambaraan umum tentang kondisi empiris bimbingan kelompok, yang kemudian disusun menjadi model hipotetik bimbingan kelompok dengan teknik outbont untuk meningkatkan kumunikasi antar pribadi mahsiswa .Berikut adalah pemaparannya:

Distribusi Frekuen

Kecakapan Komunikasi antar pribadi mahasiswa sebelum layanan

\begin{tabular}{|l|c|l|l|}
\hline Interval & Frekuensi & Prosentase & Kriteria \\
\hline $97-102$ & 5 & $17 \%$ & $\begin{array}{l}\text { Sangat } \\
\text { Rendah }\end{array}$ \\
\hline $103-108$ & 12 & $40 \%$ & Rendah \\
\hline $109-113$ & 7 & $23 \%$ & Sedang \\
\hline $114-119$ & 3 & $10 \%$ & Cukup \\
\hline $120-125$ & 2 & $7 \%$ & Tinggi \\
\hline
\end{tabular}




\begin{tabular}{|l|l|l|l|}
\hline $126-131$ & 1 & $3 \%$ & $\begin{array}{l}\text { Sangat } \\
\text { Tinggi }\end{array}$ \\
\hline Jumlah & 30 & $100 \%$ & \\
\hline
\end{tabular}

Berdasarkan data di atas, dapat dikemukakan bahwa Komunikasi antar pribadi mahasiswa sebelum pemberian layanan bimbingan kelompok dengan teknik outbond pada penelitian menghasilkan kriteria sangat rendah (17\%) sebanyak 5 mahasiswa, kriteria rendah (40\%) sebanyak 12 mahasiswa, kriteria sedang (23\%) sebanyak 7 mahasiswa, kriteria cukup (10\%) sebanyak 3 mahasiswa, kriteria tinggi (7\%) sebanyak 2 mahasiswa, dan sangat tinggi (3\%) sebanyak 1 mahasiswa.

Dengan demikian, dapat disimpulkan bahwa Komunikasi antar pribadi mahasiswa Prodi BK FKIP UPS Tegal sebelum diberikan layanan bimbingan kelompok dengan teknik Outbond, Menghasilkan interval 103 - 108, yaitu sebanyak 12 mahasiswa dengan persentase $40 \%$ yang tergolong dalam kriteria rendah. Berikutnya adalah hasil grafik histogram tentang frekuensi sebelum diberi layanan bimbingan kelompok dengan teknik outbond sebagai berikut :

\section{Gambar 5.1}

Grafik Histogran Frekuensi

Pre-Test Komunikasi antar pribadi Mahasiswa

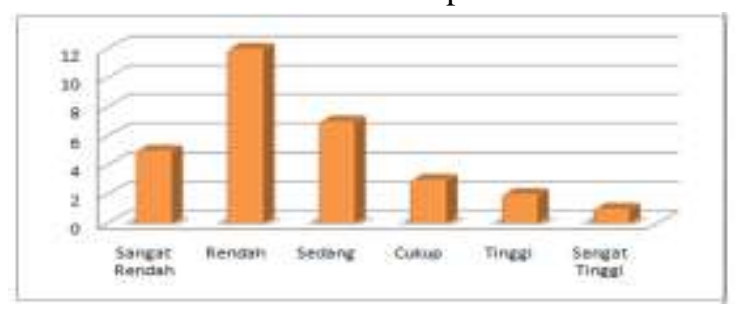

Gambar 5.2

Grafik Histogram Prosentase

Komunikasi antar pribadi Mahasiswa

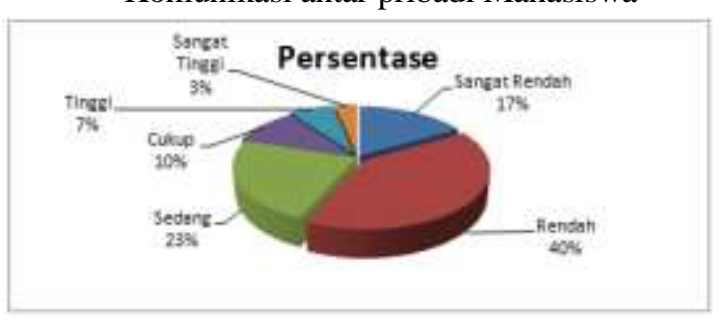

Tabel 1

Distribusi Frekuen

Kecakapan Komunikasi antar pribadi mahasiswa sesudah layanan

\begin{tabular}{|l|c|c|l|}
\hline Interval & Frekuensi & Prosentase & Kriteria \\
\hline $99-104$ & 2 & $7 \%$ & $\begin{array}{l}\text { Sangat } \\
\text { Rendah }\end{array}$ \\
\hline
\end{tabular}

\begin{tabular}{|l|c|c|l|}
\hline $105-109$ & 2 & $7 \%$ & Rendah \\
\hline $110-115$ & 4 & $13 \%$ & Sedang \\
\hline $116-120$ & 6 & $20 \%$ & Cukup \\
\hline $121-126$ & 15 & $50 \%$ & Tinggi \\
\hline $127-132$ & 1 & $3 \%$ & $\begin{array}{l}\text { Sangat } \\
\text { Tinggi }\end{array}$ \\
\hline Jumlah & 30 & $100 \%$ & \\
\hline
\end{tabular}

Berdasarkan data di atas, dapat dikemukakan bahwa Komunikasi antar pribadi mahasiswa setelah pemberian layanan bimbingan kelompok dengan teknik outbond pada penelitian menghasilkan kriteria sangat rendah $(7 \%)$ sebanyak 2 mahasiswa, kriteria rendah (7\%) sebanyak 2 mahasiswa, kriteria sedang (13\%) sebanyak 4 mahasiswa, kriteria cukup (20\%) sebanyak 6 mahasiswa, kriteria tinggi (50\%) sebanyak 15 mahasiswa, dan sangat tinggi (3\%) sebanyak 1 mahasiswa.

Dengan demikian, dapat disimpulkan bahwa Komunikasi antar pribadi mahasiswa setelah diberikan layanan bimbingan kelompok dengan teknik outbond di Prodi BK FKIP UPS Tegal , Menghasilkan interval 121 126, yaitu sebanyak 15 mahasiswa dengan persentase $50 \%$ yang tergolong dalam kriteria tinggi. Berikutnya adalah hasil grafik histogram tentang frekuensi setelah diberi layanan bimbingan kelompok dengan teknik outbond sebagai berikut :

Gambar 5.3

Grafik Histogran Frekuensi

Post-Test Komunikasi antar pribadi Mahasiswa

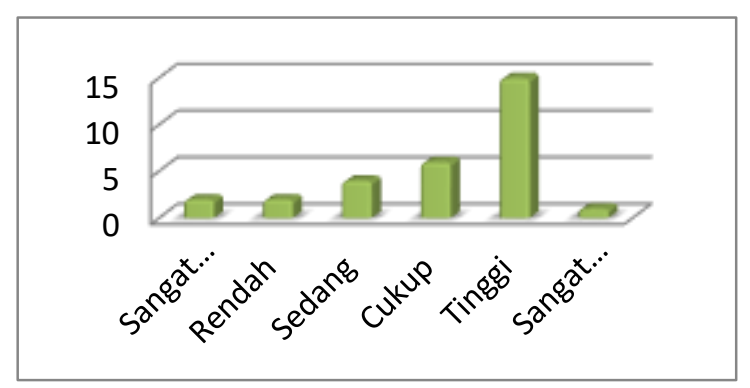

Gambar 5.4

Grafik Histogram Prosentase

Komunikasi antar Pribadi Mahasiswa

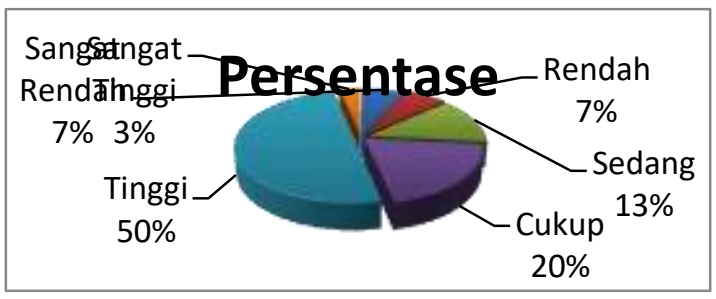


Dari hasil perhitungan di atas maka dapat dikatakan bahwa komunikasi antar pribadi mahasiswa setelah diberi layanan bimbingan kelompok melalui teknik outbond adalah sebagai berikut :

a) Memiliki tingkat komunikasi antar pribadi mahasiswa sangat rendah sebanyak 2 responden dengan prosentase $7 \%$

b) Memiliki tingkat komunikasi antar pribadi mahasiswa rendah sebanyak 2 responden dengan prosentase $7 \%$

c) Memiliki tingkat komunikasi antar mahaiswa sedang sebanyak 4 responden dengan prosentase $13 \%$

d) Memiliki tingkat komunikasi antar mahasiswa cukup sebanyak 6 responden dengan prosentase $20 \%$

e) Memiliki tingkat komunikasi antar pribadi mahasiswa tinggi sebanyak 15 responden dengan prosentase $50 \%$

f) Memiliki tingkat komunikasi antar pribadi mahasiswa sangat tinggi sebanyak 1 responden dengan prosentase $3 \%$

Hasil Komunikasi antar pribadi mahasiswa sebelum dan setelah pemberian Layanan Bimbingan Kelompok melalui Teknik Outbond.

Tabel 1

Distribusi Frekuensi

Komunikasi antar Pribadi Mahasiswa sebelum dan stelah layanan

\begin{tabular}{|c|l|c|c|l|}
\hline \multicolumn{2}{|c|}{ Sebelum } & \multicolumn{2}{c|}{ Sesudah } & Kriteria \\
\hline 5 & $17 \%$ & 2 & $7 \%$ & $\begin{array}{l}\text { Sangat } \\
\text { Rendah }\end{array}$ \\
\hline 12 & $40 \%$ & 2 & $7 \%$ & Rendah \\
\hline 7 & $23 \%$ & 4 & $13 \%$ & Sedang \\
\hline 3 & $10 \%$ & 6 & $20 \%$ & Cukup \\
\hline 2 & $7 \%$ & 15 & $50 \%$ & Tinggi \\
\hline 1 & $3 \%$ & 1 & $3 \%$ & Sangat Tinggi \\
\hline 30 & $100 \%$ & 30 & $100 \%$ & \\
\hline
\end{tabular}

Berdasarkan data diatas, dapat dikatakan bahwa komunikasi antar pribadi mahasiswa sebelum diberi layanan bimbingan kelompok melalui teknik outbond terdapat 12 mahasiswa dengan prosentase $40 \%$, berada dalam kriteria rendah. Sedangkan, setelah dilakukan layanan bimbingan kelompok melalui teknik outbond pada sampel penelitian terdapat 15 mahasiswa dengan prosentase $50 \%$, berada dalam kriteria tinggi. Dapat disimpulkan, bahwa komunikasi antar pribadi mahasiswa pada sampel penelitian sebelum dilakukan layanan bimbingan kelompok melalui teknik outbond termasuk rendah sedengkan setelah dilakukan layanan bimbingan kelompok melalui teknik outbond berada dalam kriteria tinggi. Berdasarkan tabel tersebut, maka dapat disajikan hasil grafik histogram komunikasi antar pribadi mahasiswa sebelum dan setelah diberi layanan bimbingan kelompok melalui teknik outbonnd sebagai berikut:

$$
\begin{aligned}
& 50 \therefore-\square-
\end{aligned}
$$

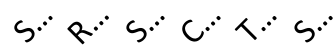

$$
\begin{aligned}
& \text { n Sebelum Sesudah }
\end{aligned}
$$

Berdasarkan grafik histagram yang diperoleh, berarti terjadi perubahan frekuensi yang amat mencolok, yaitu yang semulanya kriterianya rendah menjadi tinggi. Kondisi tersebut menunjukan, bahwa komunikasi antar pribadi mahasiswa sebelum diberi layanan bimbingan kelompok melalui teknik outbond berbeda dalam kriteria rendah. Sedang, kondisi komunikasi antar pribadi mahasiswa setelah diberi bimbingan kelompok melalui teknik outbond kelompok menjadi tinggi.

Berdasarkan hasil analisis dengan perhitungan statistik menggunakan $\mathrm{t}$-test di atas diperoleh hasil thitung $=4,763$ dengan taraf signifikansi $1 \%$ dan drajat kebebasan $\mathrm{N}-1=30-1=29$, maka didapat ttabel $=2,756$. Dengan demikian dapat dikatakan bahwa model bimbingan kelompok teknik outbond dapat meningkatkan komunikasi antar pribadi mahasiswa Prodi BK UPS Tegal.

\section{SIMPULAN DAN SARAN}

Kesimpulan dari penelitian ini bahwa Model Bimbingan Kelompok Teknik Outbond dapat meningkatkan komunikasi antar pribadi mahasiswa prodi BK FKIP UPS Tegal.Sebagai saran untuk pihak prodi lebih mendukung pelaksanaan layanan bimbingan kelompok, prodi juga mempunyai peran penting dalam mengembangkan kemampuan berinteraksi atau berkomunikasi dengan baik di kampus maupun di luar kampus.Selain itu kampus agar menyediakan berbagai sarana untuk kemudahan terlaksananya bimbingan dan konseling yang efektif.

\section{DAFTAR PUSTAKA}

Sugiyono. 2009. Metode Penelitian Kuantitatif, Kualitatif Dan R\&D. Bandung Alfabeta.

Nasirudin. 2014. Keefektifan layanan bimbingan kelompok dalam meningkatkan kemampuan komunikasi interpersonal peserta didik kelas X SMK Lab. School Pancasakti Kota Tegal Tahun Pelajaran 2013/2014. 
143 | Pengembangan Model Bimbingan Kelompok Teknik Outbond Untuk Meningkatkan Komunikasi Antar Pribadi Mahasiswa

Prayitno. 2004. Layanan Bimbingan Kelompok Konseling Kelompok. Padang : Universitas Negeri Padang.
Sugiyo. 2005. Komunkasi Antar Pribadi. Semarang :UNNESPress(http://www.ejurnal.com/2014/05/bimbi ngan-kelompok-dengan-teknik.html) 